\title{
Faaliyet Kiralaması İşlemlerinin Aktifleştirilmesinin Finansal Tablolara Ve Finansal Oranlara Etkisi Üzerine Bir Telekomunikasyon Şirketinin Vak'a İncelemesi*
}

\section{ÖZET}

Bu çalışma kapsamında, UFRS 16 Kiralamalar standardının getirdiği değişimlerin finansal tablolara ve finansal oranlara etkisinin incelenmesi amaçlanmıştır. Bu bağlamda kiracı taraf şirketlerin faaliyet kiralaması işlemlerini aktifleştirmek amacıyla akademik literatürde temel alınan yapısal aktifleştirme yöntemi kullanılmıştır. Yöntemin uygulanmasını detaylı olarak açıkladıktan sonra Borsa Istanbul'da telekomünikasyon sektöründe faaliyet gösteren Turkcell İletişim Hizmetleri A.Ş. 2015 ve 2016 finansal verileri yapısal aktifleştirme yöntemi ile incelenip, finansal tablo ve seçtiğimiz finansal oranlarda değişim incelenmiştir. Araştırma sonucunda toplam varlıkların ve toplam yükümlülüklerin aktifleştirme sonrasında artış gösterdiği ve toplam özkaynakların ise her iki yılda azalış gösterdiği görülmüşı̈̈r. Varlık kârlılığı ve özkaynak kârlılı̆ıının aktifleştirme sonrasında azaldı̆̆ı tespit edilmiş, diğer taraftan borç/özkaynak oranı ve borç/varlık oranının artış gösterdiği sonucuna varilmuştır.

Anahtar Kelimeler: Kiralama Işslemleri, Faaliyet Kiralaması, UFRS 16, Aktifleştirme.

JEL Sinıflandırması: M40, M41, M49.

The Impact of Operating Lease Capitalization On Financial Statements And Financial Ratios: A Case Study For A Telecommunication Company

\section{ABSTRACT}

The aim of this study is to examine the effects of the IFRS 16 Leases on the financial statements and financial ratios. In this context, constructive capitalization method, which is basically used in the academic literature for capitalization of lessee's operating lease contract.. After having explained the implementation of this method in detail, 2015 and 2016 financial data of Turkcell Iletişim Hizmetleri A.Ş,. which operates in the telecommunication sector in Istanbul Stock Exchange, will be analyzed by constructive capitalization method in terms of the financial statements and the financial ratios. As a result of the study, total assets and total liabilities increased after capitalization and total shareholders' equity decreased in both years. It has been found that return on assets and return on equity have decreased after the capitalization while debt to equity ratio and debt to asset ratio has increased.

Keywords: Leasing, Operating Lease, IFRS 16, Capitalisation.

Jel Classification: M40, M41, M49.

\footnotetext{
* Bu makale Galatasaray Üniversitesi Sosyal Bilimler Enstitüsü’nde Prof. Dr. İdil KAYA danışmanlığında Destan Halit AKBULUT tarafından hazırlanan "Kiralama İşlemlerinin Finansal Raporlanması ve Muhasebeleştirilmesi: Borsa İstanbul Şirketlerinde Bir Uygulama” başlıklı yüksek lisans tezinden üretilmiştir.

** Arş. Gör. Destan Halit Akbulut, Galatasaray Üniversitesi, İktisadi ve İdari Bilimler Fakültesi, dhakbulut@gsu.edu.tr
} 


\section{GİRIŞ}

Uluslararası Muhasebe Standardı 17: Kiralama İşlemleri sadece finansal kiralama işlemlerinin aktifleştirilmesini gerekli görmekteydi. Dolayısıyla faaliyet kiralaması işlemleri bilanço dışında finansal tablo dipnotlarında açıklanarak, kira giderleri ilgili oldukları dönemin gelir tablosunda gider olarak muhasebeleştirilmekteydi. Bilançoda ise faaliyet kiralaması işlemleriyle ilgili kira varlığı ve kira yükümlülüğü raporlaması yapılmamaktaydı. Böylelikle, faaliyet kiralaması yoluyla şirketler bilanço dişı finnansman yöntemlerinden biri olarak kiralamayı tercih edebilmekteydi. Bu sayede şirketler, kiralama yaparak şirketten satın alma yoluyla çıkacak olan finansmanın şirkette kalmasını sağlamak, şirket mali tablolarını daha güçlü göstermek, sermaye maliyetlerini düşürmek gibi amaçlar edinmişlerdi. Ayrıca gider gösterilen faaliyet kiralamaları yoluyla vergi avantajı da elde edilebilmekteydi (Pamukçu, 2010, Thomson, 2005, Phillips ve diğ., 2002). Ancak, bu mevcut muhasebe modelinin, akademik ve araştırmacı çevrelerce finansal tablo kullanıcılarının ihtiyaçlarını karşılamakta eksik kaldığı konusunda eleştirilmiş ve gerçeği yeterince yansıtamadığı savunulmuştur. Finansal tablo kullanıcıları tarafından bu sorunun çözülmesi talep edilmiş ve kiralama işlemleri konusunda kiracı taraf açısından, faaliyet kiralaması işlemleri ile ilgili kayıtların aktif ve pasif hesaplarda raporlanması gerekli görülmüştür (IFRS 2016a, IFRS 2016b). Özetle uluslararası finansal piyasaların gelişmesi ve bilimsel araştırmaların öngörüleri sonucunda yatırımcıların doğru kararlar alması amacıyla kaliteli, güvenilir, ihtiyaçlara cevap verebilen, gerçeğe uygun ve karşılaştırılabilir raporlama sağlayan yeni bir kiralama işlemleri standardının oluşması ihtiyacı doğmuştur.

$\mathrm{Bu}$ bağlamda değinilen Uluslararası Muhasebe Standardı 17: Kiralama İşlemleri bu ihtiyaçları karşılamakta eksik kalmış ve yenilenerek Uluslararası Finansal Raporlama Standard1 16: Kiralamalar oluşturulmuştur. Yeni yaklaşım UFRS 16 ile birlikte gerçekleşecek olan en önemli değişiklik kiracı taraf şirketler açısından faaliyet kiralaması işlemlerinin, finansal kiralama işlemleri gibi aktifleştirilip, bilançoda raporlanmasını içermektedir. Kamu Gözetimi, Muhasebe ve Denetim Standartları Kurumu da bu standardın tercümesini Türkiye Finansal Raporlama Standard1 16: Kiralamalar olarak 10 Şubat 2017'de taslak metin olarak kamuoyu görüşüne açmıştır (KGK, 2017).

Çalışmanın ilk bölümünde UFRS 16 standardının kiralama işlemlerinin raporlanmasında ortaya koyduğu temel değişimlerinin şirketlerin finansal tablolarına ve finansal oranlarına olan etkisini inceleyen çalışmalara değinilmektedir. Ayrıca değişimin temeli olan aktifleştirmenin hangi yöntemler ile yapıldığı ve araştırma kapsamında uyguladığımız yapısal aktifleştirme yönteminin temel esas ve varsayımları üzerinde durulmuştur. Daha sonra vak'a çalışmasında incelenecek olan temel finansal oranların (varlık kârlılığı, borç/özkaynak oranı, özkaynak kârlılığı, kaldıraç borç/varlık oranı) aktifleştirme öncesi ve sonrasında nasıl hesaplandığı tartışılmaktadır.

Makalenin vak'a çalışması bölümünde Borsa İstanbul'da mobil telekomünikasyon sektöründe faaliyet gösteren Turkcell İletişim Hizmetleri A.Ş. 31 Aralık 2015 ve 31 Aralık 2016 tarihinde sona eren hesap dönemlerine ait konsolide finansal tabloları ve dipnotları çerçevesinde ulaştığımız bilgiler yapısal aktifleştirme yöntemi ile incelenip, finansal tablo ve seçtiğimiz finansal oranlarda değişim olup olmadığı ve ne gibi etkilerin ortaya çıktığı üzerinde durulmaktadır. 


\section{LITTERATÜR İNCELEMESI}

Kiralama işlemlerinin şirketlerin finansal durumları dolayısıyla finansal tabloları ve finansal oranları üzerindeki etkisi birçok akademik çalışmada incelenmiştir. Çalışmanın bu bölümünde aktifleştirme yöntemleri, yapısal aktifleştirme yöntemi ve varsayımları ile UFRS 16 standardı ile ilgili Türkiye'deki çalışmalar incelenmiştir. Bu bağlamda ilk olarak literatürdeki aktifleştirme yöntemleri içerisindeki yapısal aktifleştirme yöntemi açıklanarak vak'a çalışmasına temel oluşturan dayanaklara (faiz oranı, asgari nakit akışlarının süresi, vergi oranı, aktifleştirilecek kira yükümlülüğü ve aktifleştirilecek kira varlığı) yer verilmektedir. Daha sonra araştırma kapsamında incelediğimiz varlık kârlılığı, borç/özkaynak oranı, özkaynak kârlılığı ve kaldıraç oranı hesaplamalarındaki aktifleştirme öncesi ve sonrası esaslar üzerinde durulmuş ve son olarak Türkiye'de yakın zamanda yapılan benzer çalışmalara değinilmiştir.

\subsection{Aktifleştirme Yöntemleri}

Faaliyet kiralaması işlemlerinin mevcut sisteme göre raporlanmasından kaynaklanan bilanço dışı borçların aktifleştirilmesi üzerine genel olarak bilinen iki temel yöntem ile karşılaşılmaktadır.

Birinci yöntem Imhoff ve diğerlerinin 1991 ve 1997'de yayınladıkları makalelerinde açıkladıkları yapısal aktifleştirme yöntemidir. $\mathrm{Bu}$ yöntem faaliyet kiralaması işlemlerinden kaynaklanan iskonto edilmiş gelecekteki ödemelerin bugünkü değerini hesaplayarak bilançoya ve gelir tablosuna yansıtır. Yöntemde söz konusu etkilerin tahmin edilmesi için işletmelerin yıllık faaliyet raporlarındaki açıklamalardan yararlanılmış ve bazı varsayımlar yapılmıştır.

İkinci yöntem ise akademik araştırmalarda nadiren kullanılan, genelde uluslararası kredi değerleme şirketleri ve analistler tarafından tercih edilen daha basit denebilecek faktör yöntemidir. Akademik araştırmalar büyük çoğunlukla daha doğru sonuçlar veren yapısal aktifleştirme yöntemini kullanmaktadır (Barone ve diğ. 2014).

\subsection{Yapısal Aktifleştirme Yöntemi ve Araştırma Kapsamında Esas Alınan Varsayımlar}

Araştırma kapsamında incelemesini yaptığımız şirketin finansal tablolarından ve finansal tablo dipnotlarından edindiğimiz bilgiler 1şında yapısal aktifleştirme yöntemi yapılmış ve standardın etkisi görülmeye çalışılmıştır. Bu bölümde ilk olarak yapısal aktifleştirme yöntemi açıklanmış ve daha sonra, aktifleştirme sonrası elde ettiğimiz finansal tablolardan varlık karlılığı, borç/özkaynak oranı, özkaynak karlılı̆̆ı ve kaldıraç oranı incelenmiştir.

Faaliyet kiralaması işlemlerinin aktifleştirilmesinde akademik çalışmalarda en fazla kullanılan model Imhoff ve diğerlerinin 1991 ve 1997 yıllarında geliştirdikleri yapısal aktifleştirme yöntemidir. Literatürdeki çalışmalar araştırma değişkenleri ve varsayımları üzerinde uyarlamalar yaparak bu modeli geliştirmiştir. Bölümde söz konusu modeli nasıl uyarladığımız, hangi varsayım ve kabuller ile ilerlediğimiz ve hangi değişkenleri seçtiğimiz ile yaptığımız hesaplamalar detaylıca anlatılmaktadır. 
Araştırma kapsamında hisseleri halka açık olan ve Borsa İstanbul'da telekomünikasyon sektöründe faaliyet gösteren Turkcell İletişim Hizmetleri A.Ş. firması incelenmiştir. $\mathrm{Bu}$ firmanın kamuyu aydınlatma platformunda yayınladığı yıllık konsolide finansal tabloları ve dipnotlarındaki bilgiler araştırmamızın verilerini oluşturmaktadır. Ancak yapısal aktifleştirme yönteminin uygulamasında gereken bazı bilgiler bu raporlarda bulunmadığı için uygulama kapsamında bazı varsayımlar yapılmıştır. Bunlara örnek olarak, faaliyet kiralamalarından kaynaklı bilançoda raporlanmayan kira yükümlülügünün bugünkü değerinin hesaplanması için kullanılacak faiz oranı ve söz konusu faaliyet kiralamaları kapsamındaki varlıkların kalan kiralama ömrü, bilançoda raporlanmayan faaliyet kiralaması işlemlerinden kaynaklanan kira varlığı bugünkü değeri hesaplaması, toplam kiralama ömrü ve söz konusu işlemlerdeki varlıkların türü ve dolayısıyla uygulanan amortisman yöntemi ve süresi ile ilgili varsayımlar verilebilir.

Araştırma özetle Turkcell İletişim Hizmetleri A.Ş. konsolide finansal tabloları ve dipnotlarındaki bilgiler ve varsayımlar İmhoff ve diğ. 1991 ve 1997 yıllarında geliştirdikleri yöntem çerçevesinde incelenmektedir.

Araştırmada kullanılan yapısal aktifleştirme yöntemi temel varsayımları bu bölümde açıklanacaktır. Imhoff ve diğ. 1997'de faaliyet kiralaması işlemlerinin yapısal aktifleştirilmesi üzerine yaptıkları çalışmada, 1991 yılında yapmış oldukları çalışmalarında ihmal edilebilir olarak varsaydıkları yapısal aktifleştirmenin gelir tablosu ve net kâr ile faaliyet kârı üzerine olan etkilerini incelemiştir. Çalışmaya göre gelir tablosuna olan etkiler özellikle işletme ve yönetici performanslarının tahmini, karşılaştırılması ve değerlendirilmesi açısından önem arz etmektedir. Bu bağlamda çalışmada toplam varlık kârlılığı, öz kaynak kârlılığ1 ve fiyat kazanç oranları üzerinde durulmuştur. Çalışmaya göre gerek bilanço gerek gelir tablosuna yapısal aktifleştirme yöntemini uygulayabilmek için iki önemli unsur vardır. Bunlar, faaliyet kiralamalarından kaynaklı asgari nakit akışlarını iskonto etmek için kullanılacak uygun faiz oranının belirlenmesi ve beş yıl üzerindeki faaliyet kiralamalarından kaynaklanan asgari nakit akışlarının sürelerinin tahminidir.

Bu bölümde ilk olarak faiz oranı, faaliyet kiralamalarından kaynaklanan asgari nakit akışlarının süresi ve vergi oranı ile ilgili varsayımlar ve açıklamalar yapılmaktadır. Daha sonra aktifleştirilecek (kaydedilmemiş) kira yükümlülüğü, aktifleştirilecek kira varlığ1 tutarlarının nasıl hesaplandığı açıklanmıştır. Son olarak incelediğimiz varlık kârlılığı, borç/özkaynak oranı, özkaynak kârlılığı ve kaldıraç oranı: borç/varlık aktifleştirme öncesi ve sonrası hesaplamalarının nasıl yapıldığına yer verilmektedir.

\subsubsection{Faiz Oranı}

Imhoff ve diğerlerinin 1991 yılında yaptıkları araştırmada faaliyet kiralamalarının bugünkü değerini bulmak için kullandıkları faiz oranı yüzde 10 olarak belirlenmiştir. Bu oran aynı zamanda S\&P (Standard\&Poors) faaliyet kiralamalarını aktifleştirmek amacıyla yaptıkları hesaplamalarda kullanılan orandır. Faiz oranı belirlenirken işletmelerin faaliyet kiralamalarının oluşturduğu sepet için geçerli ağırlıklandırılmış ortalama faiz oranı veya faaliyet kiralamasında saklı (zımni) faiz oranı olan marjinal faiz oranlarının ağırlıklı ortalaması seçilebilir. Ayrıca işletmenin diğer uzun vadeli borçlarının değerlemesinde kullanılacak tarihi efektif faiz oranı da kullanılabilir (Imhoff ve diğ. 1997: 16). Bu faiz oranı 
yükseldikçe hesaplanan bugünkü değer daha düşük olacaktır. Aşağıdaki tabloda sabit faiz oranı kullanan çalışmalar ve kullandıkları faiz oranları belirtilmiştir.

Tablo 1. Sabit Faiz Oranı Kullanan Çalışmalar ve Kullandıkları Faiz Oranları

\begin{tabular}{|l|r|}
\hline Sabit Faiz Oranı Kullanan Çalışmalar & Kullanılan Faiz Oranı \\
\hline Gritta 1997 & $\% 10$ \\
\hline Imhoff 1991,1993 & $\% 10$ \\
\hline Gritta, Lippman, ve Chow 1994 & $\% 10$ \\
\hline Elly 1995 & $\% 10$ \\
\hline Beattie, Edwards ve Goodacre 1998 & $\% 10$ \\
\hline Lückerath-Rovers ve De Bos 2005 & $\% 6$ \\
\hline Şenyiğit 2014 & $\%$ 6,5 \\
\hline Wong ve Joshi 2015 & $\% 9$ \\
\hline Sarı, Altıntaş ve Taş 2016 & $\% 10$ \\
\hline Ozturk ve Sercemeli 2016 & $\%$ \\
\hline
\end{tabular}

Tablo 1'de literatürde yapılan gelecekteki asgari faaliyet kiralaması taahhütlerinin bugünkü değerlerinin hesaplanmasında sabit faiz oranı kullanan çalışmalar ve çalışmaların kullandıkları faiz oranları belirtilmiştir. Buna göre araştırmaların çoğunlukla faiz oranı olarak yüzde 10’u kullanmakta olduğu görülmektedir.

\subsubsection{Asgari Nakit Akışlarının Süresi}

Bugünkü değer hesaplamasında kiralanan varlığın ekonomik ömrünün bilinmesi gelecek dönemlerin tahmini için oldukça önem teşkil etmektedir. Ancak çoğu zaman kiralama işlemleri kapsamında birçok çeşitte farklı ekonomik ömre sahip olan varlıkların kiralaması yapılmaktadır. Özellikle bu durum gıda, turizm, perakende ve taşımacılık gibi sektörlerdeki işletmelerde oldukça belirgin olarak görülmektedir (Imhoff ve diğ. 1997). Vak'a çalışmasında seçtiğimiz Turkcell İletişim Hizmetleri A.Ş. telekomünikasyon sektöründe faaliyet göstermektedir.

İnceleme kapsamında faaliyet kiralaması gelecekteki ödenecek iptal edilemeyen kira ödemesi taahhütleri yardımıyla hesaplama yapılarak asgari nakit akışlarının süresi aşağıdaki gibi tahmin edilmiştir. Faaliyet kiralaması işlemlerinden doğan kaydedilmemiş (aktifleştirilmeyen) yükümlülükleri tahmin edebilmek için öncelikle faaliyet kiralaması işlemleri ile ilgili gelecekteki nakit akışlarının sürelerinin tahmin edilmesi gerekmektedir. Sürelerin tahminini yapmak için İmhoff ve diğ. 1997'deki makalelerinde açıklanan tahmin yöntemine benzer şekilde, finansal tablo dipnotlarında vadelerine göre üç başlık olarak (vadesi beş yıldan uzun, vadesi bir ile beş yıl arasında ve vadesi bir yıldan az) açıklaması yapılan iptal edilemeyen kira sözleşmelerinden doğan gelecekteki asgari faaliyet kiralaması kira ödemeleri tutarlarının toplamını vadesi bir yıldan az olan iptal edilemeyen kira sözleşmelerinden doğan gelecekteki asgari faaliyet kiralaması kira ödemeleri tutarına bölünmüştür. Bununla ilgili hesaplama Şekil 1'de gösterilmektedir. 


$$
\mathrm{N}_{\text {Sūre }}=\frac{\mathrm{AKÖ}_{5+}+\mathrm{AKÖ}_{1-5}+\mathrm{AKÖ}_{1}}{\mathrm{AKÖ}_{1}}
$$

N Süre = Toplam asgari kira ödemelerinin tahmini kalan süresi

AKÖ = İptal edilemeyen kira sözleşmelerinden doğan gelecekteki asgari faaliyet kiralaması kira ödemeleri

AKÖ 5+ = Vadesi beş yıldan uzun olan iptal edilemeyen kira sözleşmelerinden doğan gelecekteki asgari faaliyet kiralaması kira ödemeleri

AKÖ 1-5 = Vadesi bir y1l ile beş y1l arasında olan iptal edilemeyen kira sözleşmelerinden doğan gelecekteki asgari faaliyet kiralaması kira ödemeleri

AKÖ 1 = Vadesi bir yıldan az olan iptal edilemeyen kira sözleşmelerinden doğan gelecekteki asgari faaliyet kiralaması kira ödemeleri

Şekil 1. Toplam asgari kira ödemelerinin tahmini kalan süresi

Benzer şekilde yıllık konsolide finansal tabloları ve dipnotlarındaki açıklamalar vadesi bir yıldan uzun ve beş yıldan az olan iptal edilemeyen kira sözleşmelerinden doğan gelecekteki asgari faaliyet kiralaması taahhütlerini toplam tutar olarak açıkladığından bu tutarın ortalama tahmini süresi, vadesi bir yıl ile beş yıl arasında olan iptal edilemeyen kira sözleşmelerinden doğan gelecekteki asgari faaliyet kiralaması kira ödemelerinin vadesi bir yılan az olan iptal edilemeyen kira sözleşmelerinden doğan gelecekteki asgari faaliyet kiralaması kira ödemeleri tutarına bölünmesiyle hesaplanmıştır. Bununla ilgili formül Şekil 2'de gösterilmektedir.

$$
\mathrm{N}_{1-5}=\frac{\mathrm{AKÖ}_{1-5}}{\mathrm{AKÖ}_{1}}
$$

N 1-5 = Vadesi 1 y1ldan fazla 5 yıldan az olan iptal edilemeyen kira sözleşmelerinden doğan gelecekteki asgari faaliyet kiralaması kira ödemelerinin tahmini süresi

Şekil 2. Vadesi 1 yıldan fazla 5 yıldan az olan iptal edilemeyen kira sözleşmelerinden doğan gelecekteki asgari faaliyet kiralaması kira ödemelerinin tahmini süresi

Asgari kira ödemelerinin tahmini kalan süreleri, kira yükümlülügü ve kira varlığının bugünkü değerlerinin yani aktifleştirilecek olan tutarların hesaplanmasında önemli rol oynamaktadır. Söz konusu sürenin uzun olması durumunda kira yükümlülüğünün bugünkü değeri asgari kira ödemelerinin tahmini kalan süresinin k1sa olması durumuna göre daha düşük çıkmaktadır. Bu da aktifleştirilecek olan kira varlığı ve kira yükümlülüğü tutarlarını etkilemektedir. 


\subsubsection{Vergi Oranı}

Vergi oranı aktifleştirme sonrası özkaynak değişim değeri hesaplanmasında ve kârlılık oranlarında kullanılan vergi sonrası net kârın tespitinde önemli rol oynayan bir orandır. İnceleme kapsamında vergi oranı \%20 olarak kabul edilmiştir.

\subsubsection{Aktifleştirilecek Kira Yükümlülüğü}

Kira sözleşmelerinden doğan gelecekteki asgari faaliyet kiralaması kira ödemelerinin tahmini süreleri hesaplandıktan sonra kira yükümlülügünün tahmini değeri hesaplanır. Kira yükümlülüğü hesaplaması gelecekteki asgari faaliyet kiralaması kira ödemeleri, tahmini süreler ve faiz oranı yardımıyla bugünkü değeri bulunarak yapılır. İnceleme kapsamında faiz oranı sabit oran kullanan çalışmalardaki gibi \%10 varsayılmıştır (Gritta 1997, Imhoff 1991,1993, Gritta, Lippman, ve Chow 1994, Elly 1995, Beattie, Edwards ve Goodacre 1998, Lückerath-Rovers ve De Bos 2005, Wong ve Joshi 2015, Ozturk ve Sercemeli 2016). Kira yükümlülüğünün bugünkü değeri formülü Şekil 3 ’teki gibidir.

$$
\text { Kỉra Yükümlülüğünün Bugünkü Değeri }=\frac{\mathrm{AKÖ}_{1}}{(1+\mathrm{r})^{1}}+\frac{\mathrm{AKÖ}_{1-5}}{(1+\mathrm{r})^{1-5}}+\frac{\mathrm{AKÖ}_{5+}}{(1+\mathrm{r})^{5+}}
$$

$\mathrm{r}=$ Bugünkü değer hesaplamasında kullanılan faiz oranı, (inceleme kapsamında \%10 olarak varsayılmıştır)

Şekil 3. Kira Yükümlülüğünün Bugünkü Değeri

\subsubsection{Aktifleştirilecek Kira Varlığı}

Kira yükümlülüğünün tahmini bugünkü değeri aktifleştirilecek olan tutar olarak bir önceki bölümde açıklandı. Kira varlığının tahmini bugünkü değeri ise bu bölümde hesaplanmıştır. Kira varlığının tahmini bugünkü değeri ile kira yükümlülüğü tahmini bugünkü değeri arasındaki ilişki varlık borç oranı ile kurulmaktadır. Bu sayede aktifleştirilecek kira varlığına ulaşılmıştır. Söz konusu varlık borç oranı kalan ve toplam kira ödemeleri ile bunların bugünkü değerleri ile hesaplanmıştır (Imhoff ve diğ. 1991: 56, Pettersson ve Brolin, 2014). Varlık borç oranı Şekil 4 'teki gibi formülleștirilebilir;

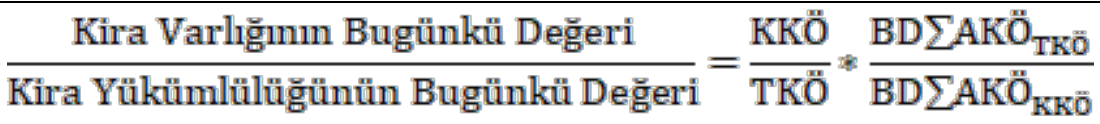

KKÖ = Kalan kiralama ömrü, TKÖ = Toplam kiralama ömrü

Şekil 4. Kira Varlığg ile Kira Yükümlülüğü İlişkisi

Varlık borç oranı hesaplamasında kullanılan kalan kiralama süresi hesap kolaylığı açısından, toplam kiralama süresinin yarısı ve ilk başta hesaplanan gelecekteki nakit akışlarının tahmini süresine eşit kabul edilmiştir ( $\mathrm{TKÖ}=2 * \mathrm{KKÖ}, \mathrm{KKÖ}=\mathrm{N}_{\text {Süre }}$ ). 


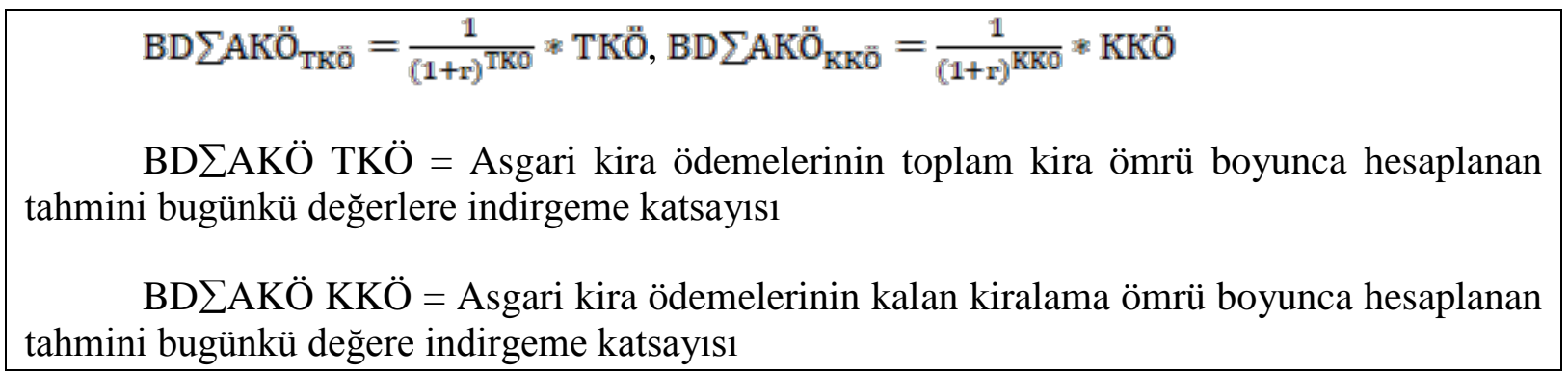

Şekil 5. Asgari kira ödemelerinin toplam ve kalan kira ömrü boyunca hesaplanan bugünkü değerlere indirgeme katsayıları

Kira varlığının bugünkü değeri ile kira yükümlülüğünün bugünkü değeri oranı Şekil 4'teki gibi hesaplandıktan sonra bu oran Şekil 6'da gösterildiği gibi hesaplanan kira yükümlülüğünün bugünkü değeri ile çarpılarak kira varlığının bugünkü değeri hesaplanır. Kira varlığının bugünkü değeri Şekil 6'daki gibi formülleştirilmiştir.

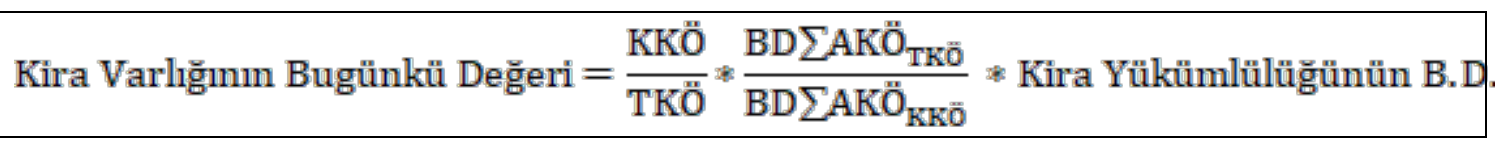

Şekil 6. Kira Varlığının Bugünkü Değeri

Dolayısıyla kira varlığının bugünkü değeri yani aktifleştirilecek olan tutar kalan ve toplam kiralama ömrü ve bunların tahmini bugünkü değerlerine göre oluşturulmaktadır.

\subsubsection{Varlık Kârlılı̆̆ı}

Kârlılık oranlarından biri olan varlık kârlılığı aktifleştirme öncesi ve sonrası incelenmek için seçilmiştir. Şekil 7'de görüldüğü gibi varlık kârlılığı raporlanan net kâr ve raporlanan toplam varlıklar oranı ile hesaplanmıştır. Aktifleştirme sonrası varlık kârlılığının tespiti için ise raporlanan net kârdan özkaynak değişim değeri çıkarılmıştır. Diğer taraftan raporlanan toplam varlıklara aktifleştirilen varlık değeri eklenmiştir. Böylelikle aktifleştirme sonrası değişimler bu orana yansıtılmıştır.

Literatürde varlık kârlılığı; Imhoff, Lipe ve Wright (1991), Imhoff, Lipe ve Wright (1993), Ely (1995), Imhoff, Lipe ve Wright (1997), Beattie, Edwards ve Goodacre (1998), Durocher (2008), Duke ve Su (2009), Wong ve Joshi (2015), Öztürk ve Serçemeli (2016) ile Sarı, Altıntaş ve Taş (2016) tarafindan incelenmiştir. 
Varlık Kârlılı̆̆ı $=\frac{\text { Raporlanan Net Kâr }}{\text { Raporlanan Toplam Varlıklar }}$

Aktifleştirme Sonrası Varlık Kârlılığı $1=\frac{\text { Raporlanan Net Kầ-0̈zkaynak Değigşim Değ̃eri }}{\text { Raporlanan Toplam Varlıklar+Aktifleştirilen Varlık Değeri }}$

Şekil 7. Aktifleştirme Öncesi ve Sonrası Varlık Kârlılığg

Aktifleştirme sonrası varlık kârlılığının hesaplanmasında kullanılan özkaynak değişim değeri kira varlık ve yükümlülügü arasındaki farkın vergi öncesi hale getirilmesi ile hesaplanmıştır. Özkaynak değişiminin vergi öncesi hale getirilmesinin nedeni varlık kârlılığı hesaplanırken daha hassas bir sonuç elde etmektir. Özkaynak Değișim Değeri = ( Kỉra Yükümlülüğgunün B.D. -Kira Varlığının B.D. ) * (1 Vergi Oram1)

\subsubsection{Borç/Özkaynak Oranı}

Borç/özkaynak oranı şirketlerin mali yapısı ile yakından ilişkili olması ve işletmenin ne ölçüde finanse edildiği, finansman risk seviyesini ve işletmenin kredi notunda etkili olan esas oranların başında gelmektedir. Borç/özkaynak oranı Şekil 8'de görüldüğü gibi raporlanan toplam yükümlülükler ile raporlanan toplam özkaynakların oranı olarak hesaplanmıştır. Aktifleştirme sonrası değişimleri gözlemleyebilmek açısından raporlanan toplam yükümlülüklere net yükümlülük değişim değeri eklenmiş, raporlanan toplam özkaynaklardan ise özkaynak değişim değeri çıkartılmıştır. Aktifleştirme sonrası özkaynak değişim değerini hesaplamak için kira yükümlülüklerinin bugünkü değeri ile kira varlığının bugünkü değeri farkı bulunup bu farktan vergi ayıklanmıştır. Böylelikle özkaynak değişimi, yani özkaynakların ne ölçüde azalacağı ve dolayısıyla net kârda yaşanacak olan değişim hesaplanmıştır.

$\begin{gathered}\text { Borç } \\ \text { Özkaynak }\end{gathered}=\frac{\text { Raporlanan Toplam Yükümlülükler }}{\text { Raporlanan Toplam Özkaynaklar }}$
$\begin{aligned} \text { Aktifleștirme SonrasıBorç/Özkaynak } \\ =\frac{\text { Raporlanan Toplam Yükümlülükler }+ \text { Net Yükümlülük Değişim Değeri }}{\text { Raporlanan Toplam Özkaynaklar - Özkaynak Değişim Değeri }}\end{aligned}$

Şekil 8. Aktifleştirme Öncesi ve Sonrası Borç Özkaynak Oranı

Aktifleştirme sonrası Borç/Özkaynak oranının hesaplanmasında kullanılan net yükümlülük değişimi değeri hesaplanması Şekil 9'da gösterilmiştir. Buna göre kira varlık ve yükümlülüğü arasındaki net fark aktifleştirilecek(kaydedilmemiş) olan kiralama yükümlülüğünden çıkarılır. 


\section{Net Yükümlülük Değişim Değeri \\ = Kaydedilmemiş Kỉra Yükümlülüğü - [Vergi Oramı \\ × (Kaydedilmemiş Kỉra Yükümlülüğü - Kaydedilmemiş Kỉra Varlığı)]}

Şekil 9. Net Yükümlülük Değeri

Literatürde borç/özkaynak oranı; Nelson (1963), Ashton (1985), Imhoff, Lipe ve Wright (1991), Imhoff, Lipe ve Wright (1993), Ely (1995), Beattie, Edwards ve Goodacre (1998), Fülbier, Silva ve Pferdehirt (2008), Duke ve Su (2009), Wong ve Joshi (2015), Öztürk ve Serçemeli (2016), Sarı, Altıntaş ve Taş (2016) ile Şenyiğit (2014) tarafından incelenmiştir.

\subsection{8. Özkaynak Kârlılığı}

Önemli kârlılık oranlarından birisi de özkaynak kârlılığıdır. Özkaynak kârlılığı vergiden sonraki net kâr ile özkaynak arasındaki ilişkiyi belirlemek için hesaplanır. Buradaki amaç, şirket ortaklarının yatırdıkları sermaye karşısında ne oranda bir getiri elde ettiklerinin hesaplanmasıdır. Şekil 10'da gösterildiği üzere özkaynak kârlılığı hesaplanırken raporlanan net kâr ile raporlanan toplam özkaynaklar oranı hesaplanmıştır. Aktifleştirme sonrası özkaynak kârlılığını hesaplamak için ise, raporlanan net kârdan özkaynak değişim değeri çıkartılmış ve aktifleştirme sonrası özkaynak değerine bölünmüştür.

$$
\text { Raporlanan Özkaynak Kârlılığı }=\frac{\text { Raporlanan Net Kâr }}{\text { Raporlanan Toplam Özkaynaklar }}
$$

Aktifleştirme Sonrası ÖzKaynak Kârlılığı

$$
=\frac{\text { Raporlanan Net Kâr }- \text { Özkaynak Değișim Değeri }}{\text { Raporlanan Toplam Özkaynaklar - Özkaynak Değişim Değeri }}
$$

Şekil 10. Aktifleştirme Öncesi ve Sonrası Özkaynak Kârlılı̆̆1

Literatürde özkaynak kârlılığı; Nelson (1963), Ashton (1985), Imhoff, Lipe ve Wright (1993), Imhoff, Lipe ve Wright (1997), Beattie, Edwards ve Goodacre (1998), Durocher (2008), Fülbier, Silva ve Pferdehirt (2008), Wong ve Joshi (2015), Öztürk ve Serçemeli (2016), Sarı, Altıntaş ve Taş (2016) ile Şenyiğit (2014) tarafından incelenmiştir.

\subsubsection{Kaldıraç Oranı: Borç/Varlık}

Borç özkaynak oranı gibi borç ile varlık oranı da işletmeler için bir diğer önemli orandır. $\mathrm{Bu}$ oran diğer bir değişle kaldıraç oranı olarak adlandırılmaktadır. İşletmeler kullandıkları borç fonları sayesinde bir seviyeye kadar özkaynak kârlılıklarını arttırabilmektedirler. Şekil 11 'de görüldügü üzere kaldıraç oranı hesaplanırken raporlanan toplam yükümlülükler ile raporlanan toplam varlıklar oranı hesaplanmıştır. Aktifleştirme sonrası kaldıraç oranı hesaplamak için ise, raporlanan toplam yükümlülüklere net yükümlülük değeri eklenmiş ve raporlanan toplam varlıklara da aktifleştirilen varlık değeri eklenmiştir. Dolayısıyla aktifleştirme sonrası değişim bulunmaya çalışılmıştır. 


\author{
Kaldıraç Oranı $=\frac{\text { Raporlanan Toplam Yükümlülükler }}{\text { Raporlanan Toplam Varlıklar }}$ \\ Aktifleştirme Sonrası Kaldıraç Oranı \\ $=\frac{\text { Raporlanan Toplam Yükümlülükler }+ \text { Net Yükümlülük Değişim Değeri }}{}$ \\ Raporlanan Toplam Varlıklar + Aktifleștirilen Varlık Değeri
}

Şekil 11. Aktifleştirme Öncesi ve Sonrası KaldıraçOranı

Literatürde borç/varlık oranı; Nelson (1963), Durocher (2008), Duke ve Su (2009), Wong ve Joshi (2015), Öztürk ve Serçemeli (2016), Sarı, Altıntaş ve Taş (2016) ile Şenyiğit (2014) tarafindan incelenmiştir.

\subsection{UFRS 16 Kiralama İşlemleri ile İlgili Türkiye'deki Çalışmalar}

Faaliyet kiralaması işlemlerine yönelik uluslararası finansal raporlama standartlarında meydan gelen değişimlerin araştırılmasını konu alan literatür incelendiğinde Şenyiğit (2014), Amerika Birleşik Devletleri'nde faaliyet gösteren bir havayolu işletmesi olan Delta Havayollarını incelemiştir. İşletmenin 2010 yılı sonrasındaki finansal kiralama ve faaliyet kiralaması ödemelerini ilk beş yıl için ayrı ayrı beş yıl ve sonrasını tek bir kalemde raporladığı şekilde incelemiş ve finansal oran olarak borç/özkaynak, uzun vadeli borç/varlık, faiz karşılama oranı, faaliyet kârı oranı, net kâr oranı ve özkaynak kârlılık oranını aktifleştirme öncesi ve sonrası olarak incelemiştir. Temel olarak borçların özsermayeye oranı ve faiz giderlerinin arttığı ve işletmenin faiz karşılama oranının düştügü sonucuna varmıştır. Ayrıca aktifleştirmeden kaynaklı oluşsan amortisman gideri ve borçlardan kaynaklı faiz giderlerinin artmasının kârlılık oranlarını azalttığı sonucuna varmıştır.

Yücel ve Adiloğlu (2016), uluslararası muhasebe standartları ile Türkiye uygulamalarını karşılaştırmış, bu kapsamda Türk Hava Yolları finansal tabloları varlık, yükümlülük, net kâr gibi kalemleri incelemiştir. Ayrıca UFRS 16 standardının finansal tablolara ve finansal oranlara etkilerini benzer şekilde Amerikan Havayolu şirketi Delta Airlines finansal tablolarından 2014 ve 2015 yılları için karşılaştırmalı olarak yorumlamıştır.

Öztürk ve Serçemeli (2016), UFRS 16 standardının finansal oranlara etkilerini incelemek amacıyla bir Türk hava yolu şirketi olan Pegasus havayollarının 2015 finansal tablo verilerini incelemiştir. Bu kapsamda borç/özkaynak, borç/varlık, varlık kârlılığı ve özkaynak kârlılığı oranlarını incelemiştir. Buna göre aktifleştirme sonrasında borç/özkaynak, borç/varlık ve özkaynak kârlılığı oranlarında artış sonucuna ulaşırken varlık kârlılığg oranında azalış sonucunu çıkarmıştır.

Sarı, Altıntaş ve Taş (2016), UFRS 16 faaliyet kiralaması işlemlerinin yapısal aktifleştirilmesinin Türk perakende sektörüne etkisini incelemiştir. Bu kapsamda Borsa İstanbul' da perakende sektöründe faaliyet gösteren 13 firmanın 2010-2014 y1lları arasındaki 
finansal tablo verileri incelenmiştir. Bu kapsamda borç/özkaynak, borç/varlık, varlık kârlılığ1 ve özkaynak kârlılığı oranlarının aktifleştirme önce ve sonrasında anlamlı şekilde değişim gösterip göstermediğini test etmiştir. Araştırma sonucunda varlık ve yükümlülüklerde anlamlı değişim sonucu bulunurken, diğer oran ve finansal tablo kalemlerinde yıllara göre farklılıklar gözlenmiştir. Bunun nedenleri arasında örneklem boyutunun azlığı ve finansal tablolardaki verilerin sınırlı olması belirtilmiştir.

Öztürk (2016), UFRS 16 standardının hava yolu şirketlerine olan etkisini incelemiştir. Bu bağlamda Türkiye ve Almanya'da faaliyet gösteren hava yolu şirketlerinin finansal ve faaliyet kiralaması işlemlerini karşılaştırmış ve söz konusu şirketlerin mali yapı analizini yaparak standardın olası etkilerini ortaya koymuştur.

Akbulut (2017), faaliyet kiralaması işlemlerinin aktifleştirilmesinin finansal tablo ve finansal oranlara olan etkisinin Borsa İstanbul şirketleri üzerinde incelemiştir. Bu bağlamda farklı sektörlerde faaliyet gösteren bu şirketlerin aktifleştirme öncesi ve sonrası finansal oranları ve finansal tabloları üzerindeki değişimlerin anlamlı olup olmadığı test edilmiştir. Yapılan analizlerin sonucunda diğer çalışmalarla paralel etkiler gözlenmekle beraber yıllar arası farklılıklar tespit edilmiştir.

Türkiye'de UFRS 16 Kiralamalar standardının faaliyet kiralaması işlemlerine yönelik getirdiği değişimleri inceleyen çalışmalar uluslararası çalışmalar ile benzer sonuçlara ulaşmıştır. Çalışmalar bu standarttan en çok etkileneceği tahmin edilen havacılık sektörü üzerine yapılmıştır, diğer yandan perakende sektörü de incelenmiştir.

Bir sonraki bölümde Türkiye'de yapılan değişik sektörlere katkı sağmak amacıyla telekomünikasyon sektöründe faaliyet gösteren Turkcell İletişim Hizmetleri A.Ş. üzerine bir vak'a incelemesi yapılacaktır.

\section{TURCELL ILETIŞIM HIZMETLERİ A.Ş. ÜZERINE VAK'A ÇALIŞMASI}

$\mathrm{Bu}$ bölümde, yapısal aktifleştirme yöntemi Borsa İstanbul'da faaliyet gösteren Turkcell İletişim Hizmetleri A.Ş. ve Bağlı Ortaklıkları şirketinin 31 Aralık 2016 ve 31 Aralık 2015 tarihinde sona eren hesap dönemlerine ait konsolide finansal tablolar ve dipnotlarından elde ettiğimiz verilere uygulanarak, karşılaştırılmalı olarak yorumlanacaktır.

İptal edilemeyen kira sözleşmelerinin gelecekteki minimum ödeme tutarlarının toplamı vadelerine göre ve faiz oranı, toplam varlıklar ve vergi oranı Tablo 2'deki gibidir. 
Tablo 2. Turkcell İletişim Hizmetleri A.Ş. 31.12. 2015 ve 31.12.2016 Tarihinde Sona Eren Hesap Dönemlerine Ait Konsolide Finansal Tablo ve Dipnotlarından Seçilmiş Veriler

\begin{tabular}{|l|r|r|}
\hline Açıklama & $\mathbf{2 0 1 5}$ & $\mathbf{2 0 1 6}$ \\
\hline Vadesi 1 yıldan az olan & 163.526 .000 & 163.336 .000 \\
Vadesi 1 yıl ile 5 yıl arasında olan & 206.030 .000 & 345.374 .000 \\
Vadesi 5 yıldan uzun olan & 7.478 .000 & 101.328 .000 \\
Faiz Oranı & 0,10 & 0,10 \\
Toplam Varlıklar & 26.184 .223 .000 & 31.600 .158 .000 \\
Vergi Oranı & 0,20 & 0,20 \\
Raporlanan Net Kâr & 2.069 .893 .000 & 1.511 .736 .000 \\
Raporlanan Toplam Yükümlülükler & 11.784 .969 .000 & 15.531 .761 .000 \\
Raporlanan Toplam Ana Ortaklığa Ait Özkaynaklar & 14.399 .254 .000 & 16.068 .397 .000 \\
\hline
\end{tabular}

Turkcell İletişim Hizmetleri A.Ş. Borsa İstanbul'da mobil telekomünikasyon sektöründe faaliyet gösteren bir şirkettir ve bundan sonra kısaca Turkcell olarak anılacaktır. Turkcell'in 31 Aralık 2016 ve 31 Aralık 2015 tarihinde sona eren hesap dönemlerine ait konsolide finansal tabloları ve dipnotlarını incelediğimizde kiralama işlemleri ile ilgili bölümde faaliyet kiralaması ile ilgili bilgilere ulaşılabilmektedir. Turkcell'in kiracı durumunda olup faaliyet kiralaması ile radyo, transmisyon hattı, ofis, internet kapasite kiralama gibi konularda sözleşmeler yapmakta olduğu görülmektedir. Söz konusu faaliyet kiralama sözleşmelerinin çeşitli bitiş tarihleri bulunmaktadır. Turkcell'in kiralama dönemi sonunda kiraladığı varlığı satın alma hakkı bulunmamaktadır (Turkcell İletişim Hizmetleri A.Ş. 2016, 2015).

Tablo 2'de görüldüğü gibi 31 Aralık 2016 (31 Aralık 2015) tarihi itibariyle iptal edilemeyen kira sözleşmelerinin gelecekteki asgari ödeme tutarlarının toplamı vadesi 1 yıldan az olan faaliyet kiralamaları taahhütleri 163.336.000 TL (163.526.000 TL), vadesi 1 yıl ile 5 y1l arasında olan faaliyet kiralamaları taahhütleri 345.374.000 TL (206.030.000 TL) ve vadesi 5 yıldan uzun olan faaliyet kiralamaları taahhütleri 101.328.000 TL (7.478.000 TL) olarak konsolide finansal tablo dipnotları içindeki Kiralama İşlemleri başlığı altında açıklanmıştır (Turkcell İletişim Hizmetleri A.Ş. 2016, 2015).

31 Aralı 2016 (31 Aralık 2015) tarihi itibariyle Turkcell toplam varlıkları 31.600.158.000 TL (26.184.223.000 TL), raporlanan net kârı 1.511.736.000 TL (2.069.893.000 TL), raporlanan toplam yükümlülükleri 15.531.761.000 TL (11.784.969.000 TL) ve raporlanan ana ortaklığa ait toplam özkaynakları 16.068.397.000 TL (14.399.254.000 TL) olarak görülmektedir.

Tablo 3. Gelecek Nakit Akışlarının Vadeye Göre Sürelerinin Tahmini

\begin{tabular}{|l|r|r|}
\hline Açıklama\Yıl & $\mathbf{2 0 1 5}$ & $\mathbf{2 0 1 6}$ \\
\hline Vadesi 1 yıla kadar & 1 & 1 \\
\hline Vadesi 1 yıl ile 5 yı1 arası: N_(1-5) & 1,25 & 2,11 \\
\hline Toplam Gelecek Nakit Akışlarının Ortalama Süresi: N_(süre) & 2,3 & 3,74 \\
\hline
\end{tabular}


Tablo 3'ten de görüldüğü üzere vadesi bir yıla kadar olan gelecek nakit akışlarının ortalama süresi her iki yıl için 1 yıl, vadesi bir yıl ile beş yıl arasında olan gelecek nakit akışlarının ortalama süresi 2015 y1lı için 1 yıl 3 ay, 2016 yılı için 2 yıl 1 ay, toplam gelecek nakit akışlarının ortalama süresi beş yıldan uzun olan faaliyet kiralaması taahhütleri ise 2015 yılı için 2 yıl 4 ay, 2016 yılı için 3 yıl 9 ay olarak tahmin edilmiştir.

Aktifleştirilecek Faaliyet Kiralaması Yükümlülüklerinin Tahmini Bugünkü Değerinin Hesaplanması: Faaliyet kiralaması kira sözleşmelerinden kaynaklı ortalama süreler tahmin edildikten sonra aktifleştirilecek kira yükümlülügünün değeri hesaplanabilmektedir. Söz konusu hesaplama için vadelerine göre asgari kira ödemeleri, faiz oranı ile bir önceki kısımda hesaplanan vadelerin ortalama tahmini sürelerine ihtiyaç duyulmaktadır. Dolayısıyla aktifleştirilecek faaliyet kiralaması yükümlülüklerinin tahmini bugünkü değeri 31.12.2016 ve 31.12.2015 yılları için sırasıyla 503.128.718 TL (342.140.165 TL) olarak hesaplanmıştır.

Toplam Kiralama Ömrü ve Kalan Kiralama Ömrü Hesaplaması: Toplam kiralama ömrü ve kalan kiralama ömrünün hesaplanması varlık/borç oranı olarak tabir ettiğimiz kira varlığının bugünkü değeri ile kira yükümlülüğünün bugünkü değeri oranı hesaplamasında kullanılacak önemli iki unsurdan biridir. Diğeri asgari kira ödemelerinin toplam kira ömrü ve kalan kiralama ömrü boyunca hesaplanan bugünkü değerlerinin oranıdır. $\mathrm{Bu}$ oranın bir sonraki aşamada değinilecektir.

Turkcell'in kiralamasını yaptığı radyo, transmisyon hattı, ofis, internet kapasite gibi varlıkların toplam kiralama süresi ve kalan kiralama süresinin tespiti oldukça zordur. Bu anlamda işlemleri kolaylaştırmak ve makul bir süre tahmin edebilmek için kalan kiralama süresini toplam gelecek nakit akışlarının ortalama süresine ve toplam kiralama süresini de kalan kiralama süresinin 2 katına eşitlenmiştir (Pettersson ve Brolin. 2014).

Tablo 4. Turkcell İletişim Hizmetleri A.Ş. 2015 ve 2016 Toplam ve Kalan Kiralama Ömrü

\begin{tabular}{|l|r|r|}
\hline Toplam Kiralama Ömrü ve Kalan Kiralama Ömrü & 2015 & 2016 \\
\hline Kalan Kiralama Ömrü & 2 & 4 \\
\hline Toplam Kiralama Ömrü & 4 & 8 \\
\hline
\end{tabular}

Asgari kira ödemelerinin toplam ve kalan kira ömrü boyunca hesaplanan bugünkü değerlere indirgeme katsayıları: Asgari kira ödemelerinin toplam ve kalan kiralama ömrü süreleri bazında faiz oranı ile birlikte tahmini bugünkü değere indirgemede kullanılan katsayı değeri hesaplaması yapılır. Bu hesaplanan katsayı değerleri ile kalan kiralama süresi ve toplam kiralama süresi yardımıyla kira varlığının bugünkü değeri ile kira yükümlülüğünün bugünkü değerinin oranı hesaplanır.

Tablo 5. Asgari kira ödemelerinin toplam ve kalan kira ömrü boyunca hesaplanan tahmini bugünkü değerlerinin toplamı

\begin{tabular}{|l|r|r|}
\hline & $\mathbf{2 0 1 5}$ & $\mathbf{2 0 1 6}$ \\
\hline BD $\sum$ AKÖ TKÖ & 2,73 & 3,73 \\
\hline BD $\sum$ AKÖ KKÖ & 1,65 & 2,73 \\
\hline
\end{tabular}


Söz konusu hesaplamalar yapıldığında toplam kiralama ömrü boyunca asgari kira ödemelerinin bugünkü değere indirgeme katsayısı 2015 ve 2016 yılları için sırasıyla 2,73 ve 3,73 ve kalan kiralama ömrü boyunca asgari kira ödemelerinin bugünkü değere indirgeme katsayısı 1,65 ve 2.73 olarak hesaplanmıştır.

Kira Varlığının Bugünkü Değeri / Kira Yükümlülüğünün Bugünkü Değeri: Kira varlığının bugünkü değerinin kira yükümlülügünün bugünkü değerine oranının hesaplanması, tahmini kira varlığını hesaplamaya yarayacaktır. $\mathrm{Bu}$ bağlamda bir önceki kısımda bulduğumuz kalan kiralama süresinin toplam kiralama süresine oranı ile toplam kiralama ömrü boyunca asgari kira ödemelerinin bugünkü değere indirgeme katsayısının kalan kiralama ömrü boyunca asgari kira ödemelerinin bugünkü değere indirgeme katsayına oranı çarpılarak söz konusu kira varlığının bugünkü değeri/kira yükümlülüğünün bugünkü değeri bulunabilmektedir.

Söz konusu hesaplamalar yapıldığında kira varlığının bugünkü değerinin kira yükümlülüğünün bugünkü değerine oranı 2015 ve 2016 yılları için 0,83 ve 0,68 olarak hesaplanmıştır.

Kira Varlığının Bugünkü Değeri: Kira varlığının bugünkü değeri yani bilançoda varlıkların ne kadar artacağını gösteren tutarın hesaplanması için kira yükümlülügünün bugünkü değeri ile kira varlığının bugünkü değerinin kira yükümlülüğünün bugünkü değerine olan oranı çarpılarak hesaplanmaktadır.

Kira varlığının bugünkü değeri 2015 ve 2016 yılları için 283.976.337,19 TL ve 342.127.528 TL olarak hesaplanmıştır. Bu tutar Turkcell'in aktifleştirme sonrasındaki bilanço toplam varlıkların artacağı tutarı belirtmektedir.

Özkaynak Değişim Değeri: Faaliyet kiralaması taahhütlerinin aktifleștirilmesinin finansal tablolara ve finansal oranlarına olan etkisini irdelerken özkaynak değişim değeri önemlilik arz etmektedir. Özkaynak etkisi, defter değeri etkisi ve net dağıtılmamış kârlar üzerindeki etki olarak da ifade edilmektedir. Bu değerin hesaplanmasında kira yükümlülüğünün bugünkü değerinden kira varlığının bugünkü değeri çıkarılır ve vergi öncesi tutar hesaplanmaktadır.

Turkcell için hesapladığımız 2015 y1lı 342.140.165 TL kira yükümlülüğünün bugünkü değeri ile 283.976.337,19 TL olan kira varlığının bugünkü değeri arasındaki farktan vergi oranı düşüldükten sonra 2015 y1lı Turkcell'in özkaynak değişim değerine ulaşılabiliriz. Böylece 2015 ve 2016 yılları için sırasıyla Turkcell özkaynak değişim değeri 46.531.062,48 TL ve 128.800.952 TL olarak hesaplanmıştır. 
Tablo 6. Yapısal Aktifleştirme Sonrası Verilerin Yıllara Göre Finansal Durum Kalemlerine Etkisi

\begin{tabular}{|l|r|r|r|}
\hline & \multicolumn{1}{|l|}{ Mevcut } & \multicolumn{1}{l|}{ Aktifleştirme Sonrası } & \multicolumn{1}{l|}{ Değişim } \\
\hline ToplamVarlıklar 2015 & 26.184 .223 .000 & 26.468 .199 .337 & 0,01085 \\
\hline Toplam Yükümlülükler 2015 & 11.784 .969 .000 & 12.127 .109 .165 & 0,02903 \\
\hline Toplam Özkaynaklar 2015 & $14.399 .254 .000,00$ & $14.352 .722 .937,52$ & $-0,0032$ \\
\hline ToplamVarlıklar 2016 & 31.600 .158 .000 & 31.942 .285 .528 & 0,01083 \\
\hline Toplam Yükümlülükler 2016 & 15.531 .761 .000 & 16.034 .889 .718 & 0,03239 \\
\hline Toplam Özkaynaklar 2016 & 16.068 .397 .000 & 15.939 .596 .048 & $-0,008$ \\
\hline
\end{tabular}

Tablo 6 incelendiğinde Turkcell İletişim Hizmetleri A.Ş.'nin 31 Aralık 2015 ve 31 Aralık 2016 tarihlerinde sona eren hesap dönemlerine ait konsolide finansal tablolar ve dipnotlarından elde edilen veriler üzerine yapılan yapısal aktifleştirme yönteminin toplam varlıklar, toplam yükümlülükler ve toplam özkaynaklar üzerindeki etkisi görülmektedir. Buna göre her iki yılda da toplam varlıkların ve toplam yükümlülüklerin aktifleştirme sonrasında beklenen şekilde artış gösterdiği görülmektedir. Toplam özkaynaklar ise her iki yılda azalış gösterdiği görülmektedir.

Tablo 7. Yapısal Aktifleştirme Sonrası Verilerin Yıllara Göre Finansal Oranlara Etkisi

\begin{tabular}{|l|r|r|r|}
\hline & \multicolumn{1}{|l|}{ Mevcut } & \multicolumn{1}{|l|}{ Aktifleştirme Sonrası } & \multicolumn{1}{l|}{ Değişim } \\
\hline Varıık Kârııı̆ı 2015 & 0,079051152 & 0,076445017 & $-0,0329677$ \\
\hline Borç/Özkaynak Oranı 2015 & 0,818443025 & 0,844934388 & 0,032367999 \\
\hline Özkaynak Kârııı̆ı̆ 2015 & 0,143750016 & 0,140974082 & $-0,01931084$ \\
\hline Borç/Varlık Oranı 2015 & 0,450079004 & 0,458176584 & 0,017991464 \\
\hline Varıık Kârııı̆̆ı 2016 & 0,047839508 & 0,043294806 & $-0,09499893$ \\
\hline Borç/Özkaynak Oranı 2016 & 0,966603016 & 1,005978424 & 0,040735863 \\
\hline Özkaynak Kârıı̆ı̆ı 2016 & 0,09408132 & 0,086760985 & $-0,07780859$ \\
\hline Borç/Varlık Oranı 2016 & 0,491508967 & 0,501995692 & 0,021335776 \\
\hline
\end{tabular}

Tablo 7'de ise yapısal aktifleştirme sonrası verilerin yıllara göre finansal oranlar üzerindeki etkileri ve değişimleri görülmektedir. Buna göre Turkcell'in varlık kârlılı̆̆ ve özkaynak kârlılığının aktifleştirme sonrasında 2015 yılı için sırasıyla \%3,3 ve \%1,9 oranında azaldığ 1 görülmektedir. Diğer taraftan borç/özkaynak oranı ve borç/varlık oranı ise 2015 yılı için sırasıyla \%3,2 ve \%1,8 oranında artış göstermiştir. Turkcell 2016 yılı verilerine yapısal aktifleştirme yöntemi uygulandığında 2015 yılı verilerine benzer şekilde varlık kârlılığı ve özkaynak kârlılığının azaldığı, borç/özkaynak oranı ile borç/varlık oranının arttığ gözlenmiştir. 
Turkcell'in 31 Aralık 2015 ve 31 Aralık 2016 tarihinde sona eren hesap dönemine ait konsolide finansal tabloları ve dipnotlarından elde edilen verilere UFRS 16: Kiralama İşlemleri Standardının getirdiği hükümlerin ve değişikliklerin önderliğinde, kabul edilen varsayımlara dayanarak yapısal aktifleştirme yöntemini uygulanmıştır. Böylece Turkcell bilançosundaki toplam varlıkların, toplam yükümlülüklerin ve toplam öz kaynakların nasıl değiştiğini gözlenmiştir. Ayrıca finansal oranlar çerçevesinde varlık kârlılığı, borç/özkaynak oranı, özkaynak kârlılığı ve borç/varlık oranının nasıl değiştiği görülmüştür. Bunları kısaca özetleyecek olursak, toplam yükümlülüklerin yaklaşık yüzde 3 arttığını, toplam varlıkların yaklaşık yüzde 1 artış gösterdiği sonucuna varılmıştır. Bunun yanı sıra incelediğimiz finansal oranlardan 2015 yılı için varlık kârlılığının yüzde 3,2 azaldığını ve özkaynak kârlılığının yüzde 1,9 azaldığını söylemek mümkündür. Borç/özkaynak oranının yüzde 3,2 arttığını, borç/varlık oranının ise yüzde 1,8 arttığını söyleyebiliriz. 2016 yılı için ise varlık kârlılığının yüzde 9,4 azaldığını ve özkaynak kârlılığının yüzde 7,8 azaldığını söylemek mümkündür. Borç/özkaynak oranının yüzde 4 arttığını, borç/varlık oranının ise yüzde 2,1 arttığını söyleyebiliriz. Dolayısıyla bütün bu oranlar ve bilanço kalemleri incelendiğinde yeni yöntemin ortaya çıkardığı farklar daha iyi görülmektedir.

\section{SONUÇ VE ÖNERILER}

Çalışma kapsamında, UMS 17 standardının kiralama işlemlerini, finansal kiralama ve faaliyet kiralaması olarak ikiye ayırması ve yalnızca finansal kiralama işlemlerinin aktifleştirmesini gerekli görmesi sonucunda oluşan problemler irdelenmeye çalışılmıştır. UMS 17 kaynaklı problemler giderilmek amaciyla Uluslararası Muhasebe Standartları Kurulu ve Amerikan Finansal Muhasebe Standartları Kurulu tarafindan UFRS 16 Kiralamalar standardı oluşturulmuştur. UFRS 16 standardının 1 Ocak 2019'da uygulanmaya başlamasıyla kiracı taraf şirketler açısından faaliyet kiralaması işlemlerinin raporlaması tıpkı UMS 17 standardındaki finansal kiralama işlemlerinin raporlaması gibi yapılmaya başlanacaktır, yani aktifleştirilip bilançoda raporlanacaktır.

Çalışma genel olarak söz konusu değişimlerin finansal tablolara ve finansal oranlara etkisini incelemeyi amaçlamıştır. Bu bağlamda kiracı taraf şirketlerin faaliyet kiralaması işlemlerini aktifleştirmek amacıyla akademik literatürde temel olarak kullanılan yapısal aktifleştirme yöntemi kullanılmıştır. Yöntemin uygulanmasını detaylı olarak açıkladıktan sonra Borsa İstanbul'da telekomünikasyon sektöründe faaliyet gösteren Turkcell İletişim Hizmetleri A.Ş. 31 Aralık 2015 ve 31 Aralık 2016 tarihinde sona eren hesap dönemlerine ait konsolide finansal tabloları ve dipnotları çerçevesinde ulaşılan bilgiler yapısal aktifleştirme yöntemi ile incelenip, finansal tablo ve seçtiğimiz finansal oranlarda değişim incelenmiştir.

Araştırma sonucunda toplam varlıkların ve toplam yükümlülüklerin aktifleştirme sonrasında artış gösterdiği; toplam özkaynakların ise her iki yılda azalış gösterdiği görülmüştür. Varlık kârlılığı ve özkaynak kârlılığının aktifleştirme sonrasında azaldığı tespit edilmiş, diğer taraftan borç/özkaynak oranı ve borç/varlık oranının artış gösterdiği sonucuna varılmıştır.

Araştırma, bir şirket üzerinde vak'a temelli detaylı bir çalışma olması ve telekomünikasyon sektörünü incelemesi açısından önemli sayılabilir. Diğer yandan farklı sektörlerin incelenmesi ve kendi içlerinde ve birbirleriyle karşılaştırılması literatüre katkı sağlayabilir. Ayrıca UFRS 16 standardının uygulamaya başlanması sonrasındaki finansal 
raporlar incelenerek beklenen değişimleri ortaya çıkarıp çıkarmadığı ile ihtiyacı karşılayıp karşılamadığı yatırımcıya yönelik kaliteli, güvenilir, ihtiyaca cevap veren, gerçeğe uygun ve karşılaştırılabilir raporlama sunma kabiliyeti açısından hangi konumda olduğu incelenebilir.

\section{KAYNAKLAR}

Akbulut, Destan Halit (2017), “Faaliyet Kiralaması İşlemlerinin Aktifleştirilmesinin Finansal Tablolara Ve Finansal Oranlara Etkisinin Borsa İstanbul Şirketleri Üzerinde İncelenmesi”, Muhasebe Bilim Dünyası Dergisi, 19(2), Haziran, ss. 456-478.

Barone, Elisabetta - Birt, Jacqueline - Moya, Soledad (2014), "Lease Accounting: A Review of Recent Literature”, Accounting In Europe, 11(1), January, pp. 35-54.

Beattie, Vivien - Edwards, Keith - Goodacre, Alan (1998), “The Impact Of Constructive Operating Lease Capitalisation On Key Accounting Ratios”, Accounting \& Business Research (Wolters Kluwer UK), 28(4), December, pp. 233-254.

Duke, Joanne C- Hsieh, Su-Jane - Su, Yuli (2009), “Operating And Synthetic Leases: Exploiting Financial Benefits In The Post-Enron Era”, Advances in Accounting, incorporating Advances in International Accounting, 25(1), June, pp. 28-39.

Durocher, Sylvain (2008), "Canadian Evidence on the Constructive Capitalization of Operating Leases”, Accounting Perspectives, 7(3), January, pp. 227-256.

Ely, Kirsten M (1995), “Operating Lease Accounting and the Market's Assessment of Equity Risk”, Journal Of Accounting Research, 33(2), pp. 397-415.

Fülbier, Rolf Uwe - Silva, Jorge Lirio - Pferdehirt, Marc Henrik (2008), “Impact Of Lease Capitalization On Financial Ratios Of Listed German Companies**”, Schmalenbach Business Review : ZFBF, 60(2), April, pp. 122-132,134-136, 138-144.

Gritta, Richard D (1974), “The Impact Of The Capitalization Of Leases On Financial Analysis, A Case Study In Air Transport”, Financial Analysts Journal, 30(2), March, pp. 47-53.

Gritta, Richard D. - Lippman, Ellen - Chow, Garland (1994), "The Impact of the Capitalization of Leases on Airline Financial Analysis: An Issue Revisited”, Logistics and Transportation Review, 30(2), June, pp. 189-202.

International Financial Reporting Standard, (2016a), "IFRS 16 Leases Effects Analysis", Çevirimiçi http://www.ifrs.org/-/media/project/leases/ifrs/published-documents/ifrs16effects-analysis.pdf (Erişim Tarihi: 8 Ocak 2017).

International Financial Reporting Standard, (2016b), “IFRS 16 Leases”, Çevirimiçi http://www.ifrs.org/issued-standards/list-of-standards/ifrs-16-leases/ (Erişim Tarihi: 8 Mart 2017). 
Imhoff Jr. Eugene A. - Lipe, Robert - Wright, David W. (1993), “The Effects of Recongition Versus Disclosure on Shareholder Risk and Executive Compensation”, Journal Of Accounting, Auditing \& Finance, 8(4), pp. 335-368.

Imhoff Jr. Eugene A. - Lipe, Robert - Wright, David W. (1997), “Operating Leases: Income Effects of Constructive”, Capitalization.Accounting Horizons, 11(2), June, pp. 12-32.

Imhoff Jr. Eugene A. - Lipe, Robert - Wright, David W. (1991), “Operating leases: Impact of constructive capitalization”, Accounting Horizons, 5(1), March, pp. 51-63.

James, Marianne L. (2016), “Accounting For Leases: A Case Exploring The Effect Of The New Lease Accounting Standard On The Financial Statements”, Journal Of The International Academy For Case Studies, 22(3), May, pp. 152-157.

Kamu Gözetimi, Muhasebe ve Denetim Standartları Kurumu, (2017), “TFRS 16 Kiralamalar Standardı Taslak Metni”, Çevirimiçi http://www.kgk.gov.tr/Portalv2Uploads/files/Duyurular/v2/TFRS/TFRS\%2016\%20Ta slak\%20Metin\%2010_02_2017.pdf(Erişim Tarihi: 15 Mart 2017).

Lückerath-Rovers, M. ve De Bos, A. (2005). The Decision Usefulness Of Operating Lease Disclosure: An Empirical Investigation Among Dutch Listed Companies.

Nelson, A. Tom (1963), “Capitalizing Leases--the Effect On Financial Ratios”, Journal of Accountancy (Pre-1986), 116(000001), July, pp. 49.

Öztürk, Can (2016), “UFRS 16 Kiralama İşlemleri Standardının Eski UMS 17 Standardı İle Karşılaştırılması Ve Almanya Ve Türkiye'de Hisse Senetleri Halka Açık Olan Hava Yolu Şirketlerinin Finansal Durumuna Etkisi”, Muhasebe Bilim Dünyası Dergisi,18(1), Mart, ss. 1-50.

Pamukçu, Ayşe (2010), "Bilanço Dışı Finansman Yöntemleri ve Muhasebeleştirme İşlemleri”, Marmara Üniversitesi İ.İ.B.F Dergisi, 29(2), ss. 479-494.

Petterson, Sebastian - Brolin, David (2014), "Proposed New Lease Standard: Do Investors Adjust For Capitalized Operating Leases In Their Assessment Of Market Value Of Equity?”, University Of Gothenbourg School Of Business, Economics and Law, pp.151.

Phillips, Lawrence C. - Munter, Paul - Robinson, Thomas R. (2002), “Understanding Leases: Accounting Issues”, Commercial Lending Review, 17(5), September, pp. 24.

Sari, Emre Selçuk - Altintas, Taylan - Tas, Nihat (2016), "The Effect of The IFRS 16 : Constructive Capitalization Of Operating Leaases In The Turkish Retailing Sector”, Journal Of Business, Economics And Finance, 5(1), pp. 138-147.

Öztürk, Meryem - Serçemeli, Murat (2016), “Impact Of New Standard “IFRS 16 Leases” On Statement Of Financial Position And Key Ratios: A Case Study On An Airline Company In Turkey”, Business and Economics Research Journal, 7(4), pp. 143-157. 
Şenyiğit, Yiğit Bora (2014), "Finansal Kiralama İşlemlerinin Muhasebeleştirilmesinde Ve Raporlanmasında Beklenen Değişiklikler: Bir Havayolu İşletmesinde Vak'a Çalışması", Ç.Ü. Sosyal Bilimler Enstitüsü Dergisi, 23(1), ss. 288-299.

Thomson, Sarah J. (2005), "The Role of Leasing in UK Corporate Financing Decisions", Discussion Paper Series in Accountancy \& Finance Heriot Watt University. pp.1-38.

Turkcell İletişim Hizmetleri A.Ş. (2015), "31 Aralık 2015 Tarihinde Sona Eren Hesap Dönemine Ait Konsolide Finansal Tablolar Ve Bağımsız Denetçi Raporu", Çevirimiçi http://s1.turkcell.com.tr/hakkimizda/tr/yatirimciiliskileri/InvestorReportLibrary/SPKReport-Q4-2015.pdf (Erişim Tarihi: 10 Mayıs 2017).

Turkcell İletişim Hizmetleri A.Ş. (2016), "31 Aralık 2016 Tarihinde Sona Eren Hesap Dönemine Ait Konsolide Finansal Tablolar Ve Bağımsız Denetçi Raporu”, Çevirimiçi http://s1.turkcell.com.tr/hakkimizda/tr/yatirimciiliskileri/InvestorReportLibrary/SPKReport-Q42016.pdf (Erişim Tarihi: 16 Haziran 2017).

Wong, Karen - Joshi, Mahesh (2015), “The Impact of Lease Capitalisation on Financial Statements and Key Ratios: Evidence from Australia” Australasian Accounting Business \& Finance Journal, 9(3), pp. 27-44.

Yücel, Göksel - Adiloğlu, Burcu (2016), "Where Are These Hidden Liabilities? IFRS 16 - A Case Of Operating Lease", İstanbul Üniversitesi İşletme Fakültesi Muhasebe Enstitüsü Seçmeler, Yayın No:75, ss. 117-129. 